\title{
Effects of brand experience, brand image and brand trust on brand building process: The case of Chinese millennial generation consumers
}

\author{
Renee B. Kim \\ School of Business, Hanyang University, \\ South Korea \\ kimrby@gmail.com \\ Yan Chao \\ School of Business, Hanyang University, \\ South Korea \\ Yanchao0223@163.com
}

Abstract. Brand researchers have been in their quest for understanding how consumers evaluate brands and react to branding practices. The purpose of this study is to validate the importance of brand experience in brand building process with high- and low-involvement products of global brands in China. Four global brands (Nike, Kappa, Ferrero, Meiji) were selected for the analysis, and 1,100 participants of the millennial generation consumers participated in the online survey. The findings suggest that both rational perception and emotional feelings of consumers play important roles in the process of brand building among Chinese consumers. The relationship between brand image and brand trust, which is the initial stage of brand building process plays a vital role in consumers' purchasing decisions. Concurrently, brand experience positively influences brand image and attachment, leading to consumers' purchasing decisions. The findings also provide insights regarding different paths in the brand building process for high and low involvement product categories, suggesting the importance of differentiated branding strategies for various product categories in China.

Keywords: brand building process, brand image, brand trust, brand experience, brand attachment, Chinese consumers, product involvement.

JEL Classification: G21, L26, O16 


\section{INTRODUCTION}

In marketing literature, researchers have been in their quest for understanding how consumers evaluate brands and respond to various branding programs (Gürhan-Canli, Sarial-Abi, \& Hayran, 2018). Strategic brand management has become an important topic for brand researchers and several conceptualizations of brand value and how branding strategies affect consumers' behaviors have been examined (Esch et al., 2006). Extensive research has proposed several branding models by incorporating important branding constructs and examining their relationships in different settings (Cleff, Walter, \& Xie, 2018; Esch et al., 2006; Walter, Cleff, \& Chu, 2013). In particular, how consumers experience brands is critical for developing marketing strategies for goods and services (Brakus et al., 2009). Brand experience is an important determinant for predicting consumers' behavioral outcomes such as customer satisfaction and loyalty/ purchase intention, both directly and indirectly. Brakus et al. (2009) claim that as a result of the effect of positive experiences, customers can become loyal. Keller (1993) states that experience may be the basis for more elaborative information processing and inference making that result in brand-related associations, and in turn, these associations may affect consumers' satisfaction and loyalty. The necessary condition for a brand to remain on the market for a long time is directly linked to the capacity to manage consumer experience (Sherry, 2005). Thus, it is imperative to understand how consumers perceive brand experience provided by brands and how brand experience affects the process of building the relationship between consumers and brand.

Asker's $(1991,1996)$ brand equity model and Keller's (1993) customer-based brand equity model are two mostly widely applied frameworks in assessing how consumers develop relationship with brands, and the measurement scales in their theoretical framework are reported to have structural validity (Yoo \& Donthu, 2001). These frameworks highlight the selected constructs such as brand image, trust and affect as important steps in building the connection between consumers and brands. Brand trust and brand affect are considered to be important determinants affecting consumers' purchase intention and brand loyalty as trust creates exchange relationship that are highly valued (Morgan \& Hunt, 1994), and positive emotional mood or affect can lead to brand loyalty and purchase intention (Dick \& Basu, 1994). In other words, brands that make consumers "happy", or "joyful", or "affectionate" should prompt greater purchase and attitudinal loyalty (Chaudhuri \& Holbrook, 2001). Brand image is another important construct in the consumer-based brand equity framework, which is defined as "a set of brand associations, usually in some meaningful way", while brand associations are "anything linked in memory to a brand" (Aaker, 1991). Aaker (1991) and Keller (1993) suggest that brand associations have a level of strength, and its link to a brand will be stronger when it is based on many experiences or exposures than when it is based on a few. The aforementioned studies evidently suggest that the process of relationship building between consumers and a brand involves multidimensions and hierarchical process.

In this study we choose to evaluate Chinese consumers' behavioral patterns regarding brand experience and brand relationship since Chinese consumers' experience with global brands is rapidly growing posing a significant market potential. Due to significant volumes of export and investment of foreign countries to China, millions of Chinese consumers have been exposed to global brands from various developed and emerging countries, showing numerous choices and preferences for global product consumption patterns (Yang, Ramsaran, \& Wibowo, 2018). Further, China has become one of the largest markets for global brands with rapidly increasing consumers' purchasing power (Villar, Di Ai, \& Segev, 2012). Global brand marketers are increasingly competing in China to gain consumers' attention, and particularly, the millennium generation of Chinese consumers are considered to be an important key consumer segment with a substantial purchasing power, thus, many global brands are striving to build a long-term relationship with this very consumer group. Villar, Di Ai, and Segev (2012) have examined Chinese consumers' brand 
preference behavior for high and low involvement products and reported differentiated choice behavior for products with different levels of involvement. Thus, it is necessary to examine Chinese consumers' brand building process for both low and high involvement product brands.

This paper aims to explore what drives Chinese millennial generation consumers in building a relationship with a brand and to evaluate whether brand experience plays a critical role in this process of brand building for high and low involvement product categories. Three determinants of consumer-based brand equity model are incorporated into our analysis to approximate the hierarchical process of brand building.

\section{LITERATURE REVIEW}

\subsection{Effects of Brand Image}

Hypotheses were developed to validate the impact of branding factors on intention to purchase consumer product category. As shown in Figure 1, a proposed model presents the hypothesized relationships among four novel brand constructs (i.e. brand image, brand trust, brand attachment, brand experience) and consumer intention to purchase two different types of product (i.e. shoes, chocolate) from four selected brands (e.g. Nike, Kappa, Ferrero, Meiji). Following Esch et al.'s (2006) suggestion, direct effect of brand image is proposed to influence behavioral intention and through the intervening effects of brand trust and brand attachment. Brand experience, which has appeared in an important study of Brakus et al. (2009) is incorporated in the model as an additional brand construct that determines brand image, trust, and attachment enhancing purchase intention.

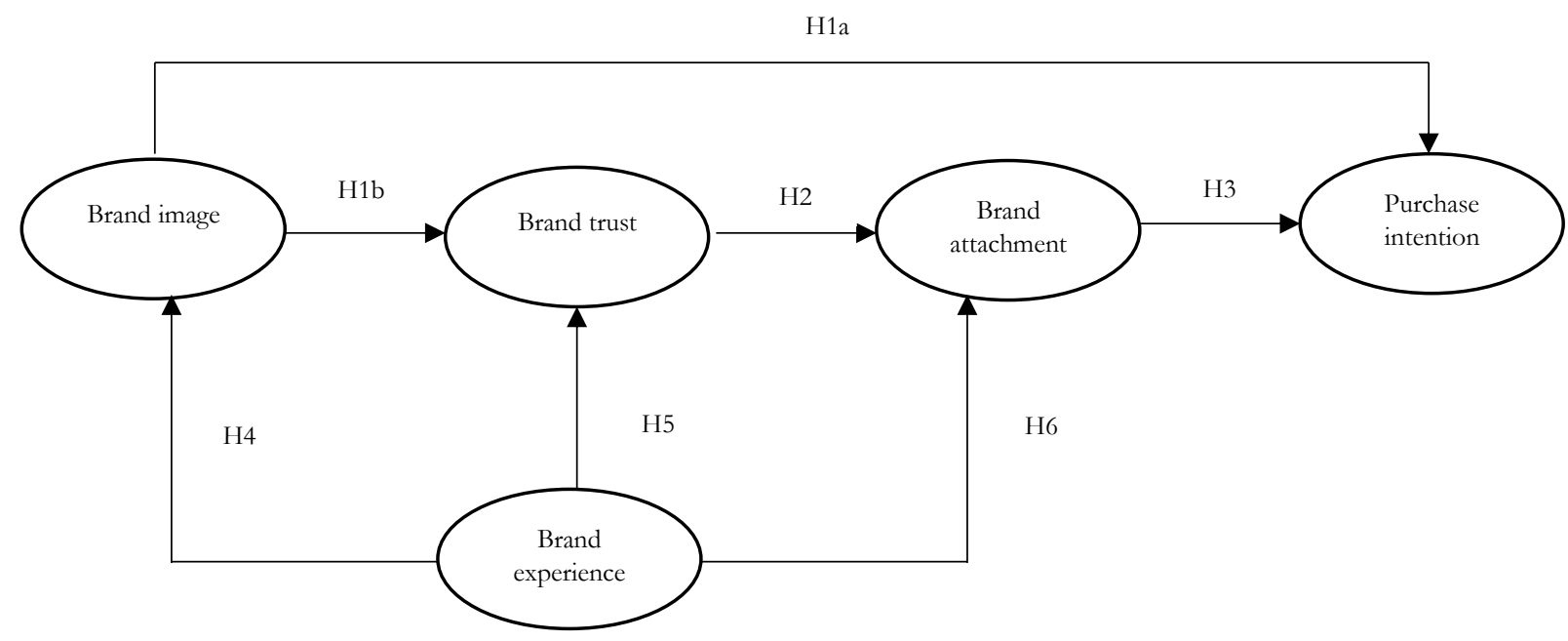

Figure 1. Theoretical framework

Drawing on Keller (1993), Woisetchläger and Michaelis (2012) define brand image as consumers' perceptions formed in their memory as reflected by brand association. The association of brand image that consumers have in their mind about a brand includes symbolic meaning and function, which are either tangible or intangible quality aspects of the particular attributes of goods or services (Persson, 2010). As such, brand image can affect how a brand is perceived by consumers in terms of quality and determine their attitudes and affection toward a brand (Esch et al., 2006), and also becomes more critical when consumers have to choose a brand over other competing brands (Anwar et al., 2011). 
According to Persson (2010), brand image is one of the main factors that drive consumers to pay a premium price and intend to purchase (Esch et al., 2006). Further, previous study shows that consumers with strong and favorable brand image are associated with trust toward a brand and have high tendency to purchase a particular brand as brand image increases their beliefs of trust (Esch et al., 2006). However, there is a paucity of a clear explanation about a relationship between these two brand constructs which has been provided by these researchers. Also, Mabkhot, Shaari, and Salleh (2017) find no significant relationship among these constructs. Hence, it is worthwhile to further take a look at these relationships and seek clearer explanation. Thus, in consistent with previous findings, this study proposes the following hypotheses:

H1a: Brand image has a positive impact on purchase intention.

H1b: Brand image has a positive impact on brand trust.

\subsection{Effect of Brand Trust}

Brand trust refers to consumers' perception about the ability of a brand to perform in accordance to its promise (Chaudhuri \& Holbrook, 2001). According to Esch et al. (2006), brand trust accelerates a level of commitment consumers have with a brand. It implies an attachment as a reflection of buyer-seller relationships at a particular point of time (Persson, 2010). Thus, such relational association seems to play an important role in consumers' willingness to purchase a brand that they trust, which shows how much they are attached to a particular brand (Esch et al., 2006). Once a company gains consumers' brand trust, their buyers tend to stick to the same brand and purchase products in different categories under it (Mabkhot, Shaari, \& Salleh, 2017), and brand trust, thereby, drives both positive attitudinal and behavioral loyalty toward a brand (Chaudhuri \& Holdbrook, 2001) and influence purchasing decision (Gefen \& Straub, 2004).

Prior research (e.g. Zboja \& Voorhee, 2006) and very recent study (e.g. Mabkhot, Shaari, \& Salleh, 2017) have, however, focused merely on the impact of brand trust on loyalty and repurchase intention, while its effect may form brand attachment as suggested by Esch et al. (2006). Accordingly, brand trust is a second important factor which is proposed in the current research model that drives consumer behavior via brand attachment. Hence, the following hypothesis is posited.

H2: Brand trust has a positive impact on brand attachment.

\subsection{Effects of Brand Attachment}

Brand attachment is an important construct which has been applied in different domains, particularly in the field of brand management to help researchers and marketers understand its consequences on consumer satisfaction, trust, commitment, and loyalty (Belaid \& Behi, 2011). In the perspective of consumer-brand relations, MacInnis and Folkes (2017); and Park et al (2010), refer brand attachment to the connection between a buyer and brand. Consumer attached to a brand can increase his or her willingness to repurchase and foster brand loyalty (Park, Eisingerich, \& Park, 2013).

Huang, Huang, and Wyer (2017) show that brand attachment can enhance consumers' tendency to brands they regularly use. It is also a factor that indicates how often consumers consume a brand in the present and the likelihood of a repeat purchase in the future (McAlexander et al., 2003; Thomson et al., 2005; Esch et al., 2006). Extent literature implies that the salient of brand attachment determines long- or short-term relationship between consumers and brands. This research tends to demonstrate that brand attachment directly affects consumer purchase intention. Given the link between these two novel constructs, Esch et al. (2006) has confirmed these important relationships. In consistent with theoretical and empirical finding, this research proposes the following hypothesis.

H3: Brand attachment has a positive impact on purchase intention. 


\subsection{Effects of Brand Experience}

Schmitt, Brakus, and Zarantoello (2015) contend that consumers seek for a consumption of brand in order to satisfy their experiential needs rather than rational price. The experiential elements include sensory, affective, behavioral, and intellectual (van der Westhuizen, 2018), which together reflect the overall degree of brands which are experienced by consumers (Brakus et al., 2009). The associations among these aspects increase interest in the brand (Jung \& Soo, 2012) and explains behavior (van der Westhuizen, 2018). Brakus et al. (2009) define brand experience as personal subjective of sensations, feelings, and cognitions evoked by external stimuli of brand, such as design and identity, packaging, communications, and environment. As such, brand-related stimuli prompt the way consumers interact with and are affected by brands.

Van der Westhuizen (2018) has tested the influence of brand experience on self-brand connection and brand loyalty. Cleff, Walter, and Xie (2018); and Iglesias, Singh, and Batista-Foguet (2011) have investigated the effect of brand experience on brand loyalty. Jung and Soo (2012) have examined the effect of brand experience on brand relationship. Also, Walter, Cleff and Chu (2013) have studied the influence of brand experience on brand personality, satisfaction, and loyalty. The aforesaid studies, however, have not looked at how brand experience would have an impact on brand image, trust, and attachment. Hence, a further investigation is called for.

Brand experience theory states that there is an opportunity for consumers to create attachment to the brand (Granitz \& Forman, 2015), thereby builds consumer-brand relationships (Schembri, 2009, Braunsberger \& Munch, 1998). It also can create deeper emotional connection to a brand leading to improved brand image (Cleff, Walter, and Xie, 2018), and brand trust (Huang, 2017; Ha \& Perks, 2005). Thus, the following hypotheses were posited to have an explicit knowledge among these branding factors.

$\mathrm{H} 4$ : Brand experience has a positive impact on brand image.

H5: Brand experience has a positive impact on brand trust.

H6: Brand experience has a positive impact on brand attachment.

\section{METHODOLOGY}

\subsection{Data Collection and Participants}

The key objective of this research is to explore how Chinese consumers form purchase intention of foreign global brands with regard to their perceptions of branding constructs. We decided to examine brand names for high and low involvement product categories (i.e. shoes and chocolate) in China, as consumers may develop different brand relationship toward high and low involvement product types. High involvement products are the one which consumers tend to exhibit extensive search process prior to purchase as this product type carry a high risk or high value, and consumer do not purchase the high involvement product frequenlty. Consumers may also consider high involvement product category as a way to express their personality, lifestyle or value. Thus, consumers are willing to go for an extensive search process for high involvement products, and this may have significant impact on their experience. On the other hand, low involvement product category are the products which consumers routinely purchase, carrying low risk or low value. Consumers may develop different extent of brand attachment to these two product categories due to different shopping journey they undergo for high and low involvement products. Key brand constructs such as brand image and brand trust may play differential role in the relationship building process as consumers show different attitudes towards high and low involvement products.

A preliminary study was conducted with 300 participants to determine most well-known brands by Chinese consumers. Findings from the preliminary study show that Nike, Kappa, Ferrero, and Meiji were found to be the most well-known brands, and chosen for the main survey study. Thus, this study focuses 
on two groups of brands (i.e. high and low involvement product brands), a link to a survey was posted in popular social networking sites(Table 1). A convenient sampling method was used to collect survey data and the survey questionnaire was designed in the Google online survey form. To collect survey data, Chinese consumers were contacted through WeChat, WhatsApp and LINE and the link to a survey questionnaire (www.google.com/forms/about) was distributed to the participants by using online method. All participants voluntarily joined a survey. We intentionally channlled to SNS to reach out to potential respondents. The respondents in this study are frequent SNS users who are in their 20s and early 30s, representing millennial consumers in China. The questionnaire was originally developed in English and had a back translation to Chinese by marketing experts. Two sets of questionnaires were produced to distinguish high involvement brands (i.e. Nike and Kappa) and low involvement brands (Ferrero and Meiji).

Respondents were introduced to a purpose of the study and required to provide a consent of study participation. After data screening, final sample of 1,100 responses were included in further data analysis. In particular, male $(n=323 ; n=206)$ and female $(n=277 ; n=294)$ provided their opinions on Nike and Kappa, and Ferrero and Meiji brands. In addition, the data showed that majority of the respondents were in their twenties (approximately $91.3 \%$ ). The participants under age 20 was $59.5 \%$ and the participant aged between 20 s and 30 s were $31.8 \%$.

Table 1

High and Low Involvement Product Types and Selected Brands

\begin{tabular}{|c|c|c|c|c|}
\hline Product Type & \multicolumn{2}{|c|}{$\begin{array}{c}\text { High-involvement product } \\
\text { /Shoes }\end{array}$} & \multicolumn{2}{c|}{ Low-involvement product /Chocolate } \\
\hline Brand & Nike & Kappa & Ferrero & Meiji \\
\hline
\end{tabular}

\subsection{Measurement}

The scales used to measure the constructs were largely drawn from existing studies, with some modifications to suit a purpose of the study. They were measured with a five point-Likert scale with anchor of $1=$ strongly disagree and $5=$ strongly agree. To measure brand image, the items were adopted from Low and Lamb (2000). The items used to measure brand trust were based on Mittal and Kamakura (2001). The brand attachment scale drew on the scale developed by Esch et al. (2006). The items to measure brand experience construct were drew on Esch et al. (2006) and Zarantonello and Schmitt (2010).

\section{EMPIRICAL RESULTS AND DISCUSSION}

\subsection{Measurement model results}

Following prior research, exploratory factor analysis (EFA) was performed prior to conducting a confirmatory factor analysis (CFA). EFA result reveals that total of thirteen items loaded on their respective construct with no cross loadings. Thus, these items were included in further analysis. Cronbach's alpha $(\alpha)$ test was performed to check the reliability of measuring items on their related factors. It shows that the reliability scores were above the level recommended by Hair et al. (2009). CFA test of structural model was conducted using AMOS 21. The results show that the overall goodness of fit of the model indices to the data collected: $x^{2} / \mathrm{df}=2.198$; GFI $=0.982$; AGFI $=0.970$; $\mathrm{NFI}=0.985 ; \mathrm{IFI}=0.992 ; \mathrm{CFI}=0.992 ; \mathrm{RMSEA}=$ 0.035 . Factor loadings were generally satisfied, convergent validity of the constructs was also examined via composite reliability (CR) and average variance extracted (AVE). Also, the results show no concerns about discrimination validity. Table 2 and 3 provide additional information on these testing results. 
Table 2

Measurement model estimation

\begin{tabular}{|c|c|c|c|c|}
\hline Constructs/items & $\begin{array}{l}\text { Factor } \\
\text { loadings }\end{array}$ & CR & $\alpha$ & AVE \\
\hline Construct 1: Brand image (BI) & & 0.90 & 0.90 & 0.75 \\
\hline I think the brand is good & $0.912^{* * *}$ & & & \\
\hline I think the brand quality is good & $0.784 * * *$ & & & \\
\hline The brand has a large influence & $0.901 * * *$ & & & \\
\hline \multicolumn{5}{|l|}{ Construct 2: Brand trust (BT) } \\
\hline I rely on the brand & $0.980 * * *$ & 0.86 & 0.84 & 0.75 \\
\hline I trust the brand & $0.736^{* * *}$ & & & \\
\hline Construct 3: Brand attachment (BA) & & 0.88 & 0.88 & 0.78 \\
\hline I feel strongly connected to the brand & $0.904 * * *$ & & & \\
\hline $\begin{array}{l}\text { I would strongly regret it if the brand was withdrawn from the } \\
\text { market }\end{array}$ & $0.864 * * *$ & & & \\
\hline Construct 4: Brand experience (BE) & & 0.92 & 0.92 & 0.78 \\
\hline $\begin{array}{l}\text { The brand impressed me deeply in the sense of sight, hearing, } \\
\text { taste, smell, and touch }\end{array}$ & $0.878 * * *$ & & & \\
\hline Using/buying the brand makes me happy & $0.864 * * *$ & & & \\
\hline The brand makes me develop feeling for it & $0.912^{* * *}$ & & & \\
\hline Construct 5: Purchase intention (PI) & & 0.90 & 0.90 & 0.74 \\
\hline How often have you bought the brand in the past? & $0.900 * * *$ & & & \\
\hline How often do you consume/use the brand? & $0.798 * * *$ & & & \\
\hline Do you intend to buy the brand in the future? & $0.885^{* * *}$ & & & \\
\hline
\end{tabular}

Table 3. Descriptive statistics, average variance extracted, and correlation matrix

\begin{tabular}{|l|r|r|r|r|r|r|r|}
\hline & \multicolumn{1}{|l|}{ Mean } & \multicolumn{1}{l|}{ SD } & \multicolumn{1}{l|}{ BE } & BI & BT & BA & \multicolumn{1}{l|}{ PI } \\
\hline BE & 3.56 & 1.28 & $\mathbf{0 . 8 8 5}$ & & & & \\
\hline BI & 3.69 & 1.11 & 0.109 & $\mathbf{0 . 8 6 8}$ & & & \\
\hline BT & 3.62 & 1.25 & 0.122 & 0.312 & $\mathbf{0 . 8 6 7}$ & & \\
\hline BA & 3.62 & 1.25 & 0.407 & 0.086 & 0.170 & $\mathbf{0 . 8 8 4}$ & \\
\hline PI & 3.72 & 1.20 & 0.214 & 0.300 & 0.254 & 0.219 & $\mathbf{0 . 8 6 2}$ \\
\hline
\end{tabular}

\subsection{Structural Equation Model (SEM) results}

SEM was conducted to test proposed hypotheses. Three models were generated. First model was tested for Nike and Kappa brands, a second model examined Ferrero and Meiji, and a third model was tested for overall combination of four brands and two products. As shown in Table 4, the proposed structural equation model shows a goodness of fit. Model 1: $x^{2} / \mathrm{df}=2.282$; GFI $=0.961$; AGFI= 0.939; NFI= 0.967; IFI= 0.981; CFI $=0.981 ; \mathrm{RMSEA}=0.051$, Model 2: $x^{2} / \mathrm{df}=1.579 ; \mathrm{GFI}=0.973 ; \mathrm{AGFI}=0.958 ; \mathrm{NFI}=0.979 ; \mathrm{IFI}=$ 0.992; $\mathrm{CFI}=0.992 ; \mathrm{RMSEA}=0.043$, Model $3: x^{2} / \mathrm{df}=2.597 ; \mathrm{GFI}=0.978 ; \mathrm{AGFI}=0.965 ; \mathrm{NFI}=0.981 ; \mathrm{IFI}=$ 
0.988; CFI $=0.988$; RMSEA $=0.040$. Table 5 presents the hypothesis results. All the hypothesized relationships with the exception of those captured by H5 in Model 1, H5, H2 and H6 in Model 2 were statistically significant providing supports to the majority of proposed links.

Table 4

\section{Model statistics}

\begin{tabular}{|c|c|c|c|}
\hline Model specification & $\begin{array}{c}\text { Nike, Kappa } \\
\text { (Model 1) }\end{array}$ & Ferrero, Meiji (Model 2) & $\begin{array}{c}\text { Full model } \\
\text { (Model 3) }\end{array}$ \\
\hline$x^{2} / \mathrm{df}$ & 2.282 & 1.579 & 2.597 \\
\hline GFI & 0.961 & 0.973 & 0.978 \\
\hline AGFI & 0.939 & 0.958 & 0.965 \\
\hline NFI & 0.967 & 0.979 & 0.981 \\
\hline IFI & 0.981 & 0.992 & 0.988 \\
\hline CFI & 0.981 & 0.992 & 0.988 \\
\hline RSMEA & 0.051 & 0.043 & 0.040 \\
\hline
\end{tabular}

Table 5

Result of hypotheses testing

\begin{tabular}{|l|c|c|c|c|c|c|}
\hline \multirow{2}{*}{ Path } & \multicolumn{2}{c|}{$\begin{array}{c}\text { Nike, Kappa } \\
\text { (Model 1) }\end{array}$} & \multicolumn{2}{c|}{$\begin{array}{c}\text { Ferrero, Meiji } \\
\text { (Model 2) }\end{array}$} & \multicolumn{2}{c|}{$\begin{array}{c}\text { Full model } \\
\text { (Model 3) }\end{array}$} \\
\hline & Coefficient & $t$-value & Coefficient & $t$-value & Coefficient & $t$-value \\
\hline H1 a: BI $\rightarrow$ PI & $0.350^{* * *}$ & 6.659 & $0.264^{* * *}$ & 5.263 & $0.311^{* * *}$ & 8.612 \\
\hline H1b: BI $\rightarrow$ BT & $0.683^{* * *}$ & 12.278 & $0.126^{*}$ & 2.060 & $0.396^{* * *}$ & 9.366 \\
\hline H2: BT $\rightarrow$ BA & $0.202^{* * *}$ & 5.029 & $0.025 n s$ & 0.732 & $0.107^{* * *}$ & 3.742 \\
\hline H3: BA $\rightarrow$ PI & $0.257^{* * *}$ & 5.166 & $0.140^{* * *}$ & 3.279 & $0.195^{* * *}$ & 5.940 \\
\hline H4: BE $\rightarrow$ BI & $0.102^{* * *}$ & 2.209 & $0.086^{*}$ & 2.249 & $0.096^{* * *}$ & 3.250 \\
\hline H5: BE $\rightarrow$ BT & $0.087 n s$ & 1.718 & $0.093 n s$ & 1.918 & $0.099^{* * *}$ & 2.731 \\
\hline H6: BE $\rightarrow$ BA & $0.570^{* * *}$ & 11.974 & $0.246^{* * *}$ & 5.276 & $0.384^{* * *}$ & 11.474 \\
\hline
\end{tabular}

Note: ${ }^{* * *} p<0.001 ;{ }^{* *} p<0.01 ;{ }^{*} p<0.05 ; n s=$ not significant

\subsection{Discussion}

The results of this study show that whether the perceptions of Chinese millennial generation consumers toward brand constructs such as brand image, trust, attachment, brand experience influence their purchase intention for global brands. Keller (1993) proposed a 'customer-based brand equity (CBBE)' model which describe a relationship building process between consumers and brand. At early stage of the CBBE process, brand awareness, image and performance of product affect consumers' rational judgement and emotional feelings toward a brand. This results in the final stage of CBBE in which consumer form loyalty, attachment or purchase intention. Our study attempt to examine the role of brand experience in the CBBE's hierarchical process, while assessing the importance of these selected brand constructs in the CBBE model.

Overall, Brand image effect on Brand trust was found to be most influential in brand building process, while brand experience's effect on brand attachment was found to be second most important factor in this process. This suggests that at early stage of brand building process, brand image appears to have significant impact on building consumers' trust, while consumers' experience tend to affect their attachment to brand at later stage of the process.

Brand image also had statistically significant direct impact on purchase intention. On the other hand, brand experience's effect on other intermediate construct such as brand image and brand trust were found 
to be least important. The relationship between brand trust and brand attachment was also found to be less important in the brand building process.

At large, the initial stage of brand building process (i.e. the relationship between Brand image to Brand trust) appears to be critical in the overall process, and brand experience appears to have significant impact on brand attachment which is the later stage of brand building process. Thus, the hierarchical brand building process is influenced how Chinese consumers perceive brand quality, image and how much they trust the brand (i.e. Brand image and Brand trust) at early stage, and the process is also affected at later stage by whether consumers have positive sensory and emotional experience and whether they feel connected to the brand (i.e. Brand experience and Brand attachment). Thus, consumers establish long-term relationship with brands based not only on cognitive-utilitarian dimensions, but also on affective dimensions based on the collective interactions they had experienced with the brand (Fournier 1998 \& 2009). However, the connection between brand trust and brand attachment was found to be relatively weak compared to other link in the hierarchical brand building process.

In order to distinguish Chinese consumers' choice behavior for high and low involvement products, we developed two separate models of brand building process. Results showed interesting difference. For high involvement product category, the initial stage (the relationship between brand image and brand trust) was also found to be the most significant in the hierarchical process of brand building. On the other hand, the direct effect of brand image on purchase intention was found to be most influential for low involvement product category. This result provide interesting insights for consumers' behavior for high and low involvement products. When consumers are considering high involvement product purchase, it is important for them to go through hierarchical process, and how they perceive brand image significant affect their trust in the brand, leading to the following stages. Brand trust also has a positive effect on brand attachment only in the case of high involvement brands (i.e. Nike and Kappa). This may be possibly explained by the nature of product characteristics which impact a degree of connection between consumers and the brands. Highinvolvement products requires consumers to engage in extensive searching activities, comparing prices, and evaluating product quality so that this can be some of the possible consequences of high brand attachment.

In contrast, for purchasing situation of low involvement product, consumers' perception of brand image affect purchase intention directly, and the subsequent stages of hierarchical brand building process may not be as important in this case. However, for both high and low involvement product scenarios, the relationship between brand experience and brand attachment was found to be similarly important and playing critical role in brand building process. From this finding, we can draw an important finding that brand image and trust of brand building process unfold in different manner for high and low involvement products, yet experiential aspect of brand building process appear to play equally critical role for the two types of product purchase scenarios.

The result also indicates that brand attachment positively influences purchase intention for both high and low involvement product types. Thus, brand attachment is considered as an influential outcome of brand image and brand trust. The finding of this study reveals that brand experience has a positive influence on brand image and attachment. However, a relationship between brand experience and trust was found to be insignificant. Zarantonello and Schimitt (2010)'s brand experience scale suggest four dimensions (i.e. sensory, affective, behavioral and intellectural), sensory and affective aspects of brand experience may play greater role in Chinese context. In other words, Chinese consumers' sensory and affective experience of brand may reinforce them to feel connected to brand, perceiving brand in positive way. 


\section{CONCLUSION}

This study provides meaningful contributions to existing literature of Chinese millennial generation consumers' choice behavior for global brands. Chinese millennial consumer group is an important potential consumers, representing 415 million. They make up more than $30 \%$ of the China's population. This consumer group is well travelled, tech savy, constantly connected to online, making up $92 \%$ of the Internet users in China. Thus, it is worthwhile to explore how this consumer group develop their relationship with global brands. Prior research, for instance, Yang, Ramsaran, and Wibowo (2018) build a brand framework of global dairy product through an investigation the effect of country-of-origin into Chinese consumers' perceptions, this current study proposes a comprehensive research model incorporating novel brand factors which have been studied in the previous research to examine purchase intention of four international brands with two different product categories. In particular, this study examined the hierarchical process of brand building for high and low involvement product types.

Findings show that the initial stage of hierarchical brand building process increase consumers' purchase intention for brands. In other word, how consumers perceive brand quality and reputation affect their trust toward the brand, and this has critical role in leading the following stages of brand building process, resulting in purchase intention. The result is closely related to the study of Esch et al. (2006), whereby it was found that Chinese global brand buyers consider brand image to be the critical factor when purchasing shoes and chocolate. In addition, Chinese consumers' sensory experience of brand and their perception of connectivity with the brand lead to emotional attachment which result in purchase intention. Thus, brand experience appears to be important initial antecedent which play a vital role in engaging consumer's emotion to the brand.

We further elaborated the hierarchical brand building process for high and low involvement process, and provided insights to different development of consumers' relationship with brand for different level of involvement products. Findings suggest that it is important to recognize earning consumers' trust by building a good brand image and product quality if a marketer is building brand relationship for high involvement products. However, this may not be the case for low involvement product scenario, as consumers' perception of brand image directly affect their purchase intention, and consumers may not go through series of stages to make decision for brand purchase.

Nonetheless, marketers should recognize the important role of providing proper brand experience and evoke positive feelings for both high and low involvement products in order to persuade consumers. Without effective brand experience, marketers cannot assume that consumers' trust for brand naturally lead to brand attachment and purchase intention. This is particularly true for low involvement product case, as brand trust do not lead to brand attachment in this scenario. Thus, marketers are encouraged to shift their focus to brand experience to enhance image, trust, and attachment via experiential marketing strategies for high- and low-involvement products. For instance, firms should pay attention to effectively formulating strategy that relates to customer-focused and creating memorable experiences of product and service offered rather than merely emphasizing functional benefits, features, and performance because sensory aspects such as five senses give people an idea about a brand when they search for, shop for, and consume brands (Brakus et al., 2009), which leads to alternative behaviors.

\section{ACKNOWLEDGEMENT}

This work was supported by the Ministry of Education of the Republic of Korea and the National Research Foundation of Korea(NRF-2016S1A3A2924243) 


\section{REFERENCES}

Aaker, D.A. (1996). Building strong brands, free press, New York, NY.

Aaker, D.A. (1991). Managing brand equioty, free press, New York, NY.

Anwar, A., Gulzar, A., Sohail, F.B., \& Aram, S.N. (2011). Impact of brand image, trust and affect on consumer brand extension attitude: The mediating role of brand loyalty. International Journal of Economics and Management Sciences, 1(5), 73-79.

Brakus, J.J., Schmitt, B.H., \& Zarantello, L. (2009). Brand experience: What is it? How is it measured? Does it affect loyalty? Journal of Marketing, 73(3), 52-68.

Belaid, S., \& Behi, A.T. (2011). The role of attachment in building consumer-brand relationships: An empirical investigation in the utilitarian consumption context. Journal of Product $\mho$ Brand Management, 20(1), 37-47.

Braunsberger, K., \& Munch, J.M. (1998). Source expertise versus experience effects in hospital advertising. Journal of Services Marketing, 12(1), 23-38.

Cleff, T., Walter, N., \& Xie, J. (2018). The effect of online brand experience on brand loyalty: A web of emotions. The IUO Journal of Brand Management, 15(10), 7-24.

Chaudhuri, A., \& Holbrook, M.B. (2001). The chain of effects from brand trust and brand affect to brand performance: the role of brand loyalty. Journal of Marketing, 65, 81-93.

Dick, A.S. and K.Basu (1994). Customer loyalty: toward an integrated conceptual framework, Journal of the Academy of Marketing Science, 22, 99-113.

Esch FR, Langner T, Schmitt B, Geus P. Are brands forever? How knowledge and relationships affect current and future purchases. J Prod Brand Manag 2006;15(2):98-105.

Fournier, S. (1998) Consumers and their brands: developing relationship theory in consumer research. Journal of Consumer Research 24(4): 343-353.

Fournier, S. (2009) Lessons learned about consumers' relationships with their brands. In: D.J. Macinnis, C.W. Park and J.R. Priester (eds.) Handbook of Brand Relationships. New York: M.E. Sharpe, pp. 523.

Gürhan-Canli, Z., Sarial-Abi, G., \& Hayran, C. (2018). Consumers and brands across the globe: Research synthesis and new directions. Journal of International Marketing, 26(1), 96-117.

Gefen, D., \& Straub, D.W. (2004). Consumer trust in B2C e-commerce and the importance of social presence: Experiments in e-products and e-services. Omega - The International Journal of Management Science, 32, 407-24.

Granitz, N., \& Forman, H. (2015). Building self-brand connections: Exploring brand stories through a transmedia perspective. Journal of Brand Management, 22(1), 38-58.

Hair, J.F. Jr., Black, W.C., Babin, B.J., Anderson, R.F., \& Tatham, R.L. (2009). Multivariate Data analysis, Pearson Prentice Hall, Upper Saddle River, NJ.

Huang, X., Huang, Z., \& Wyer Jr, R.S. (2017). The influence of social crowding on brand attachment. Journal of Consumer Research, 44, 1068-1084. 
Huang, C.C. (2017). The impacts of brand experiences in brand loyalty: Mediators of brand love and trust. Management Decision, 55(5), 915-934.

Ha, H.Y., \& Perks, H. (2005). Effects of consumer perceptions of brand experience on the web: Brand familiarity, satisfaction and brand trust. Journal of Consumer Behavior, 4(6), 438-452.

Iglesias, O., Singh, J.J., \& Batista-Foguet, J.M. (2011). The role of brand experience and affective commitment in determining brand loyalty. Journal of Brand Management, 18(8), 570, 582.

Jung, L.H., \& Soo, K.M. (2012). The effect of brand experience on brand relationship quality. Academy of Marketing Studies Journal, 16(1), 87-98.

Keller, K.L. (1993). Conceptualizing, measuring, and managing customer-based brand equity, Journal of Marketing, 57, 1-22.

Low, G.S., \& Lamb, C.W. Jr. (2000). The measurement and dimensionality of brand associations. Journal of Product \& Brand Management, 9(6), 350-70.

Mabkhot, H.A., Shaari, H., \& Salleh, S.M. (2017). The influence of brand image and brand personality on brand loyalty, mediating by brand trust: An empirical study. Journal Pengurusan, 50, 1-18.

Mittal, V., \& Kamakura, W.A. (2001). Satisfaction, repurchase intent and repurchase behavior: Investigating the moderating effect of customer characteristics. Journal of Marketing Research, 38, 131-42.

MacInnis, D.J., \& Valerie S. F. (2017). Humanizing brands: When brands seem to be like me, part of me, and in a relationship with me. Journal of Consumer Psychology, 27(3), 355-74.

Morgan, R. M. and Shelby d. Hunt (1994). The commitment -trust theory of relationship marketing, Journal of Marketing, 58, 20-38.

Park, C.W., Andreas, B.E., \& Park, J.W. (2013). Attachment-aversion (AA) model of customer- brand relationships. Journal of Consumer Psychology, 23(2), 229-48.

Park, C.W, Deborah J.M., Priester, J., Andreas, B.E., \& Iacobucci, D. (2010). Brand attachment and brand attitude strength: Conceptual and empirical differentiation of two critical brand equity drivers. Journal of Marketing, 74(6), 1-17.

Persson, N. (2010). An exploratory investigation of the elements of B2B brand image and its relationship to price premium. Industrial Marketing Management, 39, 1269-1277.

Sherry, J.F. (2005) Brand meaning. In: A.M. Tybout and T. Calkins (eds.) Kellog on Branding. Hoboken: John Wiley \& Sons, pp. 40-69.

Schmitt, B., Brakus, J.J., \& Zarantonello, L. (2015). From experiential psychology to consumer experience. Journal of Consumer Psychology, 25(1), 166-171.

Schembri, S. (2009). Reframing brand experience: The experiential meaning of Harley-Davidson. Journal of Business Research, 62(12), 1299-1310.

Van der Westhuizen, L.M. (2018). Brand loyalty: Exploring self-brand connection and brand experience. Journal of Product \& Brand Management, 27(2), 172-184.

Villar, M.E., Ai, D., \& Segev, S. (2012). Chinese and American perceptions of foreign-name brands. Journal of Product \& Brand Management, 21(5), 341-349. 
Walter, N., Cleff, T., \& Chu, G. (2013). Brand experience's influence on customer satisfaction and loyalty: A mirage in marketing research? International Journal of Management Research and Business Strategy, 2(1), 130-144.

Woisetschläger, D.M., \& Michaelis, M. (2012). Sponsorship congruence and brand image: A pre-post event analysis. European Journal of Marketing, 46(3/4), 509-523.

Yang, R., Ramsaran, R., \& Wibowo, S. (2018). An investigation into the perceptions of Chinese consumers towards the country-of-origin of dairy products. International Journal of Consumer Studies, 42, 205-216.

Zboja, J.J., \& Voorhees, C.M. (2006). The impact of brand trust and satisfaction on retailer repurchase intention. Journal of Services Marketing, 20(6), 381-390.

Zarantonello, L., \& Schmitt, B.H. (2010). Using the brand experience scale to profile consumers and predict consumer behavior. Journal of Brand Management, 17(7), 532-540. 